\title{
SOME ASPECTS OF LIVING CONDITIONS OF POPULATION IN THE SMALL TOWNS AT THE ZONE OF INFLUENCE NEAR THE LARGE-SCALE CITIES (ON THE EXAMPLE OF KYIV AND KHARKIV)
}

\author{
Svitlana CHEMERYS \\ Institute of Geography, National Academy of Sciences, Kyiv, Ukraine \\ svetapetruk@mail.ru
}

\begin{abstract}
In the paper the questions are considered about the change of living conditions for the population of small towns which are situated in the neighborhood of large-scale cities, on the example of Kyiv and Kharkiv. A great attention is taken to economical pre-conditions which have influence on the formation of living conditions for population, as a budget of town, a level of unemployment of people and an average salary of people. The analysis is given for the separate aspects of social component for the formation of living conditions of population in small towns. All indexes have been analyzed for the group of small towns in the neighborhood of Kyiv and Kharkiv. To provide a comparison and study of biggest cities influence the analysis was performed also for the group of small towns of both regions which were not included into the urban agglomerations. It was established a correlation between change of living conditions of population and distance from the large-scale cities.
\end{abstract}

Key words: small towns, living conditions, urban agglomeration, large-scale cities, distribution of population.

UDC: 911.3

\section{ДЕЯКІ АСПЕКТИ УМОВ ЖИТТЯ НАСЕЛЕННЯ В МАЛИХ МІСТАХ У ЗОНІ ВПЛИВУ НАЙБІЛЬШИХ МІСТ (НА ПРИКЛАДІ КИЄВА ТА ХАРКОВА)}

\author{
Світлана ЧЕМЕРИС \\ Інститут географії НАН України, м. Київ \\ svetapetruk@mail.ru
}

\begin{abstract}
Анотація: У статті розглядаються питання зміни умов життя населення малих міст, що знаходяться в оточенні найбільших міст, на прикладі Києва та Харкова. Значна увага приділена економічним передумовам, що впливають на формування умов життя населення, зокрема бюджет міста, рівень безробіття населення та середня заробітна плата населення. Проаналізовано окремі аспекти соціальної складової умов життя населення малих міст. Всі показники аналізувалися для групи малих міст, в оточенні Києва та Харкова. Для порівняння й виявлення впливу найбільших міст аналіз проводився також для групи малих міст в обох областях, що не входять до складу агломерацій. Прослідковано зміни умов життя населення з віддаленістю від найбільших міст.
\end{abstract}

Ключові слова: малі міста, умови життя, міська агломерація, найбільші міста, розселення населення.

удк: 911.3

Вступ. За останні два десятиліття в Україні відбулися значні соціально-економічні зміни. Це переважно негативно позначилося на більшості малих міст, де спостерігаються процеси занепаду промисловості, інфраструктури, зростання безробіття та падіння рівня життя населення. Оскільки серед чинників розселення часто домінує економічний, малі міста переважно втрачають населення, яке виїздить до великих міст. Великі міста приваблюють можливостями: робочими місцями, вищими зарплатами, можливостями культурного та самостійного розвитку. Значні темпи урбанізації зумовили формування навколо ряду великих міст агломерацій, для яких характерна висока територіальна концентрація різноманітних виробництв, насамперед, промисловості, інфраструктурних об’єктів, наукових і навчальних закладів, висока густота населення в межах агломерації. Між центром агломерації та навколишніми малими містами встановлюються стійкі виробничі, трудові, транспортні, культурні та інші види зв'язків, причому не тільки виключно

(C) С. Чемерис доцентрові. Ці процеси впливають на умови та спосіб життя населення малих міст, що входять до складу агломерацій.

Умови життя населення визначаються потенціалом території населеного пункту, де проживає людина, сюди можна віднести природні умови, умови праці, розміри доходу, обсяг і структуру споживання матеріальних благ, забезпеченість житлом, умови та необхідність ведення особистого підсобного господарства тощо [4]. Для малих міст, а також приміських поселень великих міст характерні так звані - урбо-руральні умови життя населення, тобто такі, де ознаки міського комфорту i благоустрою часто поєднуються із зайнятістю в аграрній та суміжній сферах [9]. I навіть, якщо люди, проживаючи в межах агломерації, працюють у великому місті, їх побут і життя вдома часто пов'язані із підсобним сільським господарством. Саме від умов життя, в яких проживає населення, як вважає I. В. Гукалова, залежить їх рівень життя та формується якість життя [3].

Аналіз останніх досліджень та публікацій. Питанню дослідження міст, включаючи малі міста, присвячені роботи багатьох вітчизняних та зарубіж- 
них вчених, таких як Ю.І.Пітюренко, А.І. Доценко, П.С. Коваленко, А.С.Степаненко, В.В.Загородній, В.О.Джаман, А.А.Мозговий та ін. Умови життя населення та особливості його життєдіяльності розглядаються в працях М.І.Фащевського, І. В. Гукалової, С. О. Ковальова, Е. М. Лібанової та ін. Однак актуальним залишається питання дослідження малих міст, що входять до складу агломерацій, виявлення змін, що відбулися у структурі та функціях цих поселень, умовах життя населення.

Виклад основного матеріалу. Малі міста, що знаходяться в зоні впливу великих та найбільших міст, виділяються серед інших малих міських поселень. Життя їх населення безпосередньо пов’язане із великим містом. Міські агломерації сприяють прискоренню змін господарської та просторової структур малих міст, що входять до їх складу. У них відбувається диверсифікація господарства, можуть змінюватися старі та формуватися нові функції, яких вони не виконували за межами агломерацій. Малі міста характеризуються тісними соціальноекономічними та культурно-побутовими зв'язками 3 центром агломерації. Вони приваблюють резервними більш дешевими територіями для винесення частини промислових об'єктів, офісів, складів до малих міст, в оточення центру агломерації. Особливо це стосується малих міст, що знаходяться вздовж головних транспортних магістралей. У них відбувається пожвавлення житлової забудови, будівництва «другого» житла для мешканців великого міста, створення зон відпочинку.

Пожвавлення економічної та містобудівної діяльності призводить до створення нових робочих місць, покращення транспортної доступності до населеного пункту та компенсує закриття частини промислових підприємств, підвищує інвестиційну та міграційну привабливість малих міст. Таким чином, на відміну від більшості малих міст, які характеризуються кризовим станом, малі міста, що знаходяться в зоні впливу найбільших міст відрізняються більшою динамікою розвитку.

Для аналізу впливу найбільших міст на умови життя населення малих міст було обрано 2 моноцентричні агломерації - Київську ${ }^{1}$ та Харківську (табл. 1). Обрані малі міста знаходяться у 30-40 км доступності до центрів своїх агломерацій та пов'язані 3 ними транспортними шляхами, що дозволяє населенню досить швидко дістатися до великого міста. Більшість малих міст $є$ районними центрами (Васильків, Боярка, Обухів у Київській області, Чугуїв у Харківській області). Вони виконують організаційно-управлінські функції по відношенню до навколишньої території. Частина 3 обраних малих міст $\epsilon$ історичними. Найдавнішими є м. Вишгород (946 рік заснування) та м. Васильків (988р.). Міста Харківської області засновані переважно у 17 столітті, зокрема м. Чугуїв (1627 рік), м.Люботин у середині XVII століття. Вони віднесені до списку історичних поселень України, що затверджений Постановою Кабінету Міністрів України від 26.01.2001 року № 878 [6].

Для порівняння у кожній області було обрано ще декілька малих міст, які не входять до складу міських агломерацій (табл. 2). Ці міста також переважно є районними центрами, 3 віддаленістю від центру агломерації більше 50 км. Частина 3 них теж $є$ історичними поселеннями (м. Богуслав 1195 рік заснування, смт Ржищів XI-XII ст., м. Фастів 1390 р., м. Яготин 1552 р., м. Валки 1646 р., м. Балаклія 1663 р.), що закріплено Постановою Кабінету Міністрів України від 26.01.2001 року № 878 .

Таблиия 1

Окремі показники малих міст, що входять до досліджуваних агломерацій

\begin{tabular}{|c|c|c|c|c|c|c|c|c|}
\hline & \multirow[t]{2}{*}{$\begin{array}{c}\text { Площа, } \\
\text { км }^{2}\end{array}$} & \multirow{2}{*}{$\begin{array}{c}\text { Відстань } \\
\text { до центру } \\
\text { агломерації } \\
\text { автошляхами, } \\
\text { км } \\
\end{array}$} & \multirow{2}{*}{$\begin{array}{c}\text { Густота, } \\
\text { осіб/км }{ }^{2}, \\
2009 \text { р. }\end{array}$} & \multirow{2}{*}{$\begin{array}{c}\text { Густота } \\
\text { ociб/кM }^{2} \\
2014 \text { p. }\end{array}$} & \multirow{2}{*}{$\begin{array}{l}\text { різниця } \\
\text { густоти, } \\
\text { осіб/км }\end{array}$} & \multicolumn{2}{|c|}{$\begin{array}{c}\text { чисельність } \\
\text { населення, } \\
\text { осіб }\end{array}$} & \multirow{2}{*}{$\begin{array}{c}\% \\
\text { чисельност } \\
\text { населення } \\
2014 \text { до } \\
2009 \text { р. }\end{array}$} \\
\hline & & & & & & 2009 & 2014 & \\
\hline \multicolumn{9}{|c|}{ Київська область } \\
\hline Ірпінь & 110,83 & 8 & 362,7 & 397 & 34,3 & 40200 & 44000 & 109,5 \\
\hline Васильків & 21,03 & 35,5 & 1745,1 & 1749,9 & 4,8 & 36700 & 36800 & 100,3 \\
\hline Боярка & 13 & 27,9 & 2661,5 & 2730,8 & 69,3 & 34600 & 35500 & 102,6 \\
\hline Обухів & 24,2 & 45 & 1343 & 1371,9 & 28,9 & 32500 & 33200 & 102,2 \\
\hline Буча & 26,57 & 30 & 1016,2 & 1121,6 & 105,4 & 27000 & 29800 & 110,4 \\
\hline Українка & 5,91 & 36 & 2538,1 & 2656,5 & 118,4 & 15000 & 15700 & 104,7 \\
\hline \multicolumn{9}{|c|}{ Харківська область } \\
\hline Чугуїв & 12,77 & 20 & 2568,5 & 2537,2 & $-31,3$ & 32800 & 32400 & 98,8 \\
\hline Люботин & 31,1 & 25 & 704,2 & 701 & $-3,2$ & 21900 & 21800 & 99,5 \\
\hline
\end{tabular}

Складено за матеріалами $[1,2]$

료 дослідження обрані лише ті малі міста Київської агломерації для яких наявна статистична база 
Важливим показником стану малих міст є динаміка чисельності їх населення. Порівнюючи показники табл. 1 i 2, можна відмітити, що для малих міст, які знаходяться у зоні впливу Києва та Харкова, характерне зростання або незначне зменшення чисельності та густоти населення. Малі міста, що входять до складу Київської агломерації характеризуються стійкою тенденцією до збільшення обох показників. Найбільший приріст чисельності населення характерний у м. Буча (на 10 \%) та м. Ірпінь (на 9,5 \%) (табл. 1). Густота населення найбільше зросла у містах Вишгород, Українка, Буча. Це міста, що мають переважно незначну відстань до великого міста та зручний транспортний зв'язок 3 ним. Темпи зростання чисельності та густоти населення часто залежать від відстані до центрального міста (смт. Коцюбинське, Вишневе) і так званої «елітності» населених пунктів (Ворзель, Буча). Для малих міст Харківської агломерації характерне зменшення чисельності населення порівняно 3 показниками 2009 р. Однак 32012 р. у м. Чугуїв спостерігається поступове зростання чисельності населення. Хоча слід зазначити, що темпи зменшення чисельності населення у малих містах у складі агломерацій нижчі, ніж в малих містах на периферії областей. За темпами зменшення чисельності населення виділяються міста Барвінкове $(11,5 \%)$ й Тараща (5,9 \%) (табл. 2).

Умови життя населення $€$ поняття багатоаспектним, адже включає природну, соціальну та економічну підсистеми. На формування умов життя населення, окрім природного середовища, значний вплив мають економічні та соціальні процеси, які відбуваються в державі та безпосередньо впливають на стабільність та комфортність життя населення.

Важливу роль відіграють економічні передумови формування умов життя населення. Зокрема бюджет міста, його доходи та видатки ілюструють, чи залишаються ресурси для розвитку соціальної інфраструктури, доріг, житлово-комунального господарства. Як видно з рис. 1 більшість малих міст, що знаходяться у складі агломерацій, покривають свої видатки за рахунок власних доходів. Однак у малих містах Харківської агломерації (Чугуїв, Люботин) доходи ледве перевищують витрати, тобто на розвиток міста й оновлення інфраструктури коштів майже не залишається. Дефіцит бюджету характерний переважно для малих міст, що не знаходяться в зоні впливу великого міста. Це м. Тараща, Фастів, Валки, які відповідно є дотаційними, і на благоустрій міст коштів залишається мало.

Аналізуючи показники ринку праці, які також відносять до економічних передумов умов життя населення, слід зазначити, що стан ринку праці малих міст, що знаходяться в складі різних агломерацій, неоднаковий. Малі міста, що входять до Київської агломерації (рис. 2), характеризуються нижчими показниками рівня безробіття (Ірпінь, Українка), це може пояснюватися впливом міста Києва та зайнятістю значної частини населення у столиці. Малі міста в оточенні Харкова (Люботин, Чугуїв) характеризуються вищим рівнем безробіття. Загалом рівень безробіття у малих містах 3 наближенням до великого міста зменшується оскільки частина трудових ресурсів зайнята у великому місті та щодня здійснює трудові маятникові міграції до центру агломерації. Це зумовлено відсутністю робочих місць у малому місті та вищим рівнем оплати праці за ту саму роботу у великому місті. 3 віддаленням від центру агломерацій та великих міст мобільність населення менше, а рівень безробіття зростає, що пов'язано із закриттях підприємств у більшості малих міст або суттєвим скорочення обсягів виробництва та кількості працюючих.

Важливе значення також відіграє розмір заробітної плати. Адже рівень доходів впливає на якість та умови життя населення. Як видно $з$ рис. 3,

Таблиия 2

Окремі показники малих міст Київської та Харківської областей, що не входять до міських агломерацій

\begin{tabular}{|c|c|c|c|c|c|c|c|c|}
\hline & \multirow[t]{2}{*}{$\begin{array}{c}\text { Площа, } \\
\text { км }^{2}\end{array}$} & \multirow{2}{*}{$\begin{array}{c}\text { Відстань } \\
\text { до центру } \\
\text { агломерації } \\
\text { автошляхами, } \\
\text { км } \\
\end{array}$} & \multirow[t]{2}{*}{$\begin{array}{c}\text { Густота } \\
\text { осіб/км², } \\
2009 \text { р. }\end{array}$} & \multirow{2}{*}{$\begin{array}{c}\text { Густота } \\
\text { осіб/км², } \\
2014 \text { p. }\end{array}$} & \multirow[t]{2}{*}{$\begin{array}{l}\text { різниця } \\
\text { густоти, } \\
\text { осіб/км² }\end{array}$} & \multicolumn{2}{|c|}{$\begin{array}{c}\text { чисельність } \\
\text { населення, } \\
\text { осіб }\end{array}$} & \multirow{2}{*}{$\begin{array}{c}\% \\
\text { чисельності } \\
\text { населення } \\
2014 \text { до } \\
2009 \text { р. }\end{array}$} \\
\hline & & & & & & 2009 & 2014 & \\
\hline \multicolumn{9}{|c|}{ Київська область } \\
\hline Сквира & 63,28 & 121 & 270,2 & 262,3 & $-7,9$ & 17100 & 16600 & 97,1 \\
\hline Тараща & 36,96 & 115 & 322 & 303 & -19 & 11900 & 11200 & 94,1 \\
\hline Ржищів & 35,6 & 76 & 216,3 & 210,7 & $-5,6$ & 7700 & 7500 & 97,4 \\
\hline Фастів & 43 & 73 & 1134,9 & 1116,3 & $-18,6$ & 48800 & 48000 & 98,4 \\
\hline \multicolumn{9}{|c|}{ Харківська область } \\
\hline Первомайський & 9 & 90 & 343,1 & 344,2 & 1,12 & 30883 & 30984 & 100,33 \\
\hline Куп'янськ & & 124 & 243,7 & 235,8 & $-7,8$ & 30217 & 29247 & 96,79 \\
\hline Валки & 13 & 54,6 & 738,5 & 715,4 & $-23,1$ & 9600 & 9300 & 96,9 \\
\hline
\end{tabular}

Складено за матеріалами $[1,2]$ 


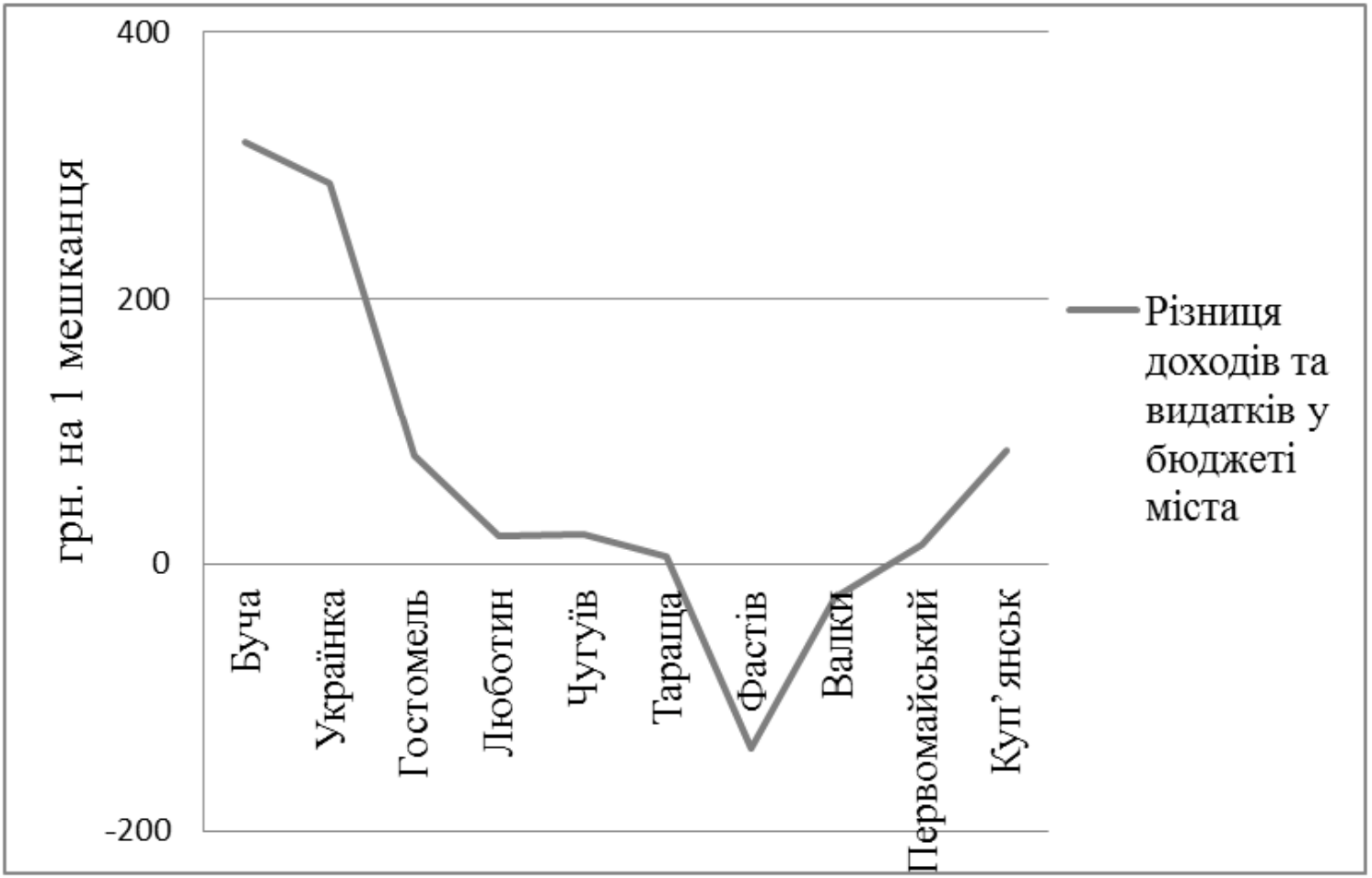

Рис. 1. Бюджети окремих малих міст, 2010 р. Складено за матеріалами [7]

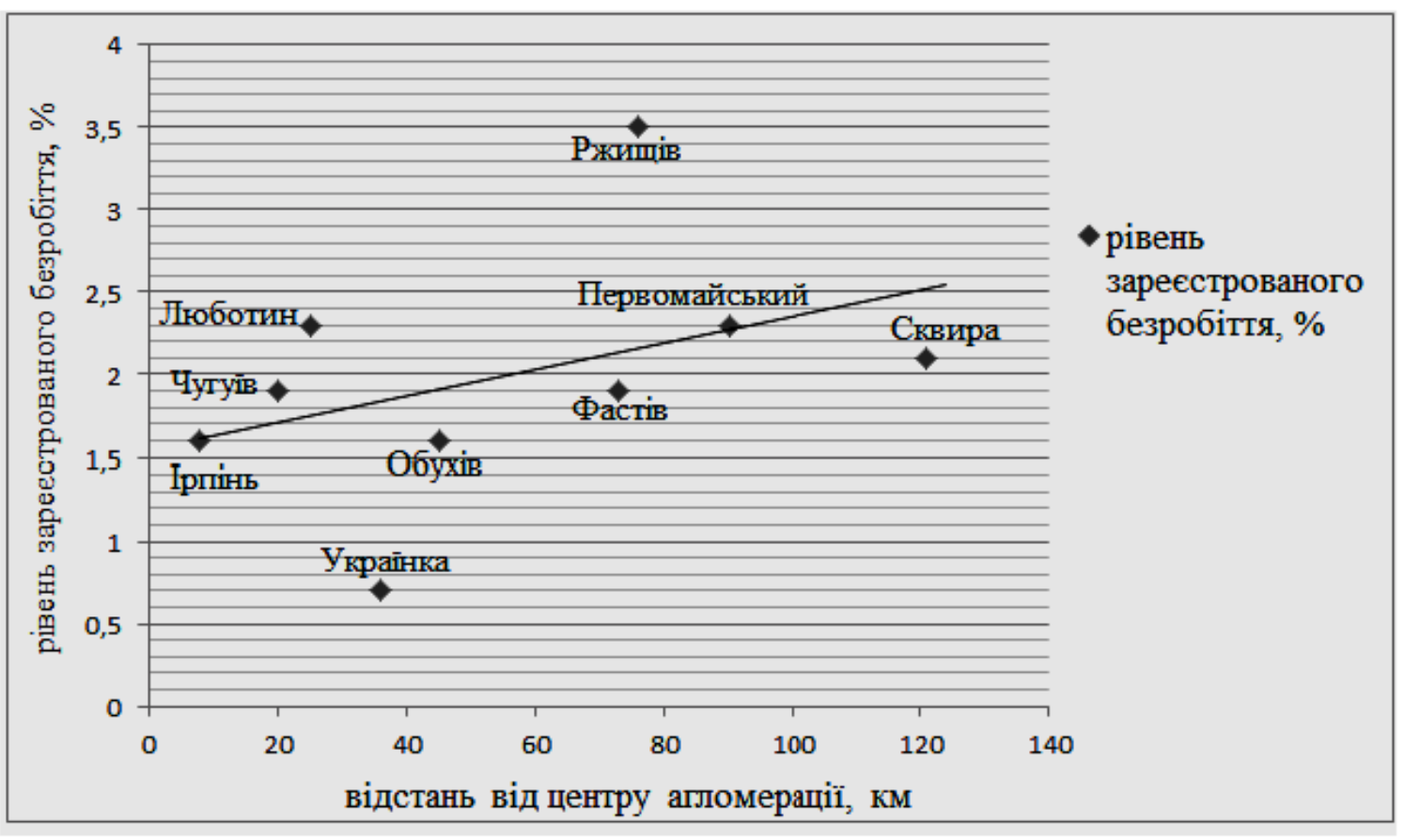

Рис. 2. Рівень зареєстрованого безробіття, 2010, \%. Складено за матеріалами [7]

малі міста, що входять до складу агломерації, характеризуються вищим рівнем оплати праці, наприклад, м. Обухів, Буча, Васильків. Це пояснюється декількома причинами: зайнятість значної частки трудового населення у великому місті та винесенням до малих міст частини фірм, складів та невеликих підприємств 3 центру агломерацій зі збереженням в них заробітної плати як у великому місті. У деяких малих містах, наприклад Обухів, Фастів, вищий рівень заробітної плати пов'язаний iз спеціалізацією міста (теплоелектроенергетика та залізничний транспорт) і відповідним рівнем зарплат у галузі. Малі міста на периферії регіонів характеризуються нижчим рівнем заробітної плати, часто за ті самі види робіт. Таким чином, чим далі від центру агломерацій, тим нижчим $є$ рівень середньої заробітної плати. Хоча, слід зазначити, що наближеність до столиці з їі вищими зарплатами частково нівелюється значно вищою вартістю життя населення, ніж на периферії.

Соціальна інфраструктура є однією з важливих складових, що формують умови життя населення, 


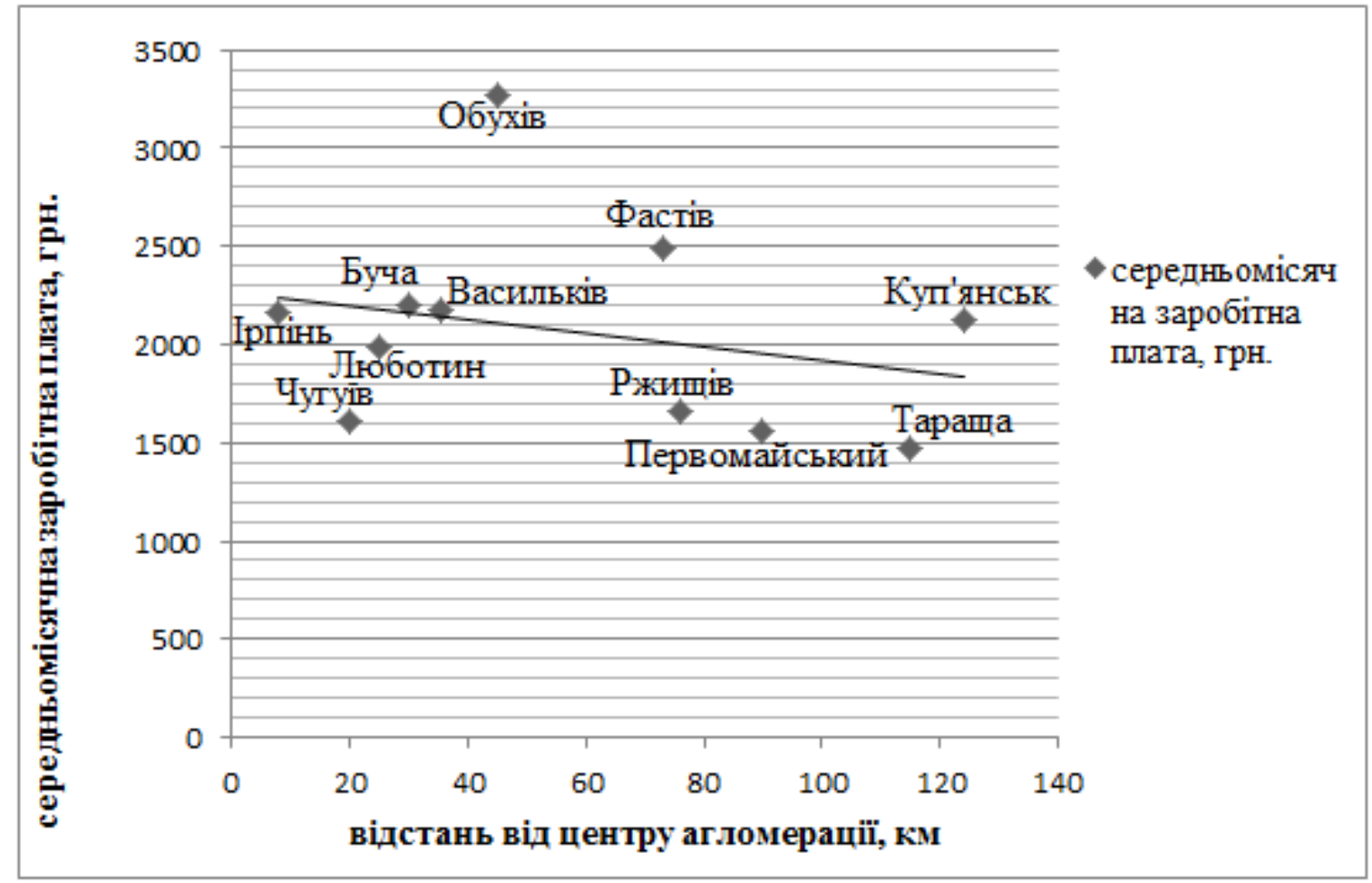

Рис. 3. Розмір середньомісячної заробітної плати, грн., 2010 р. Складено за матеріалами [7]

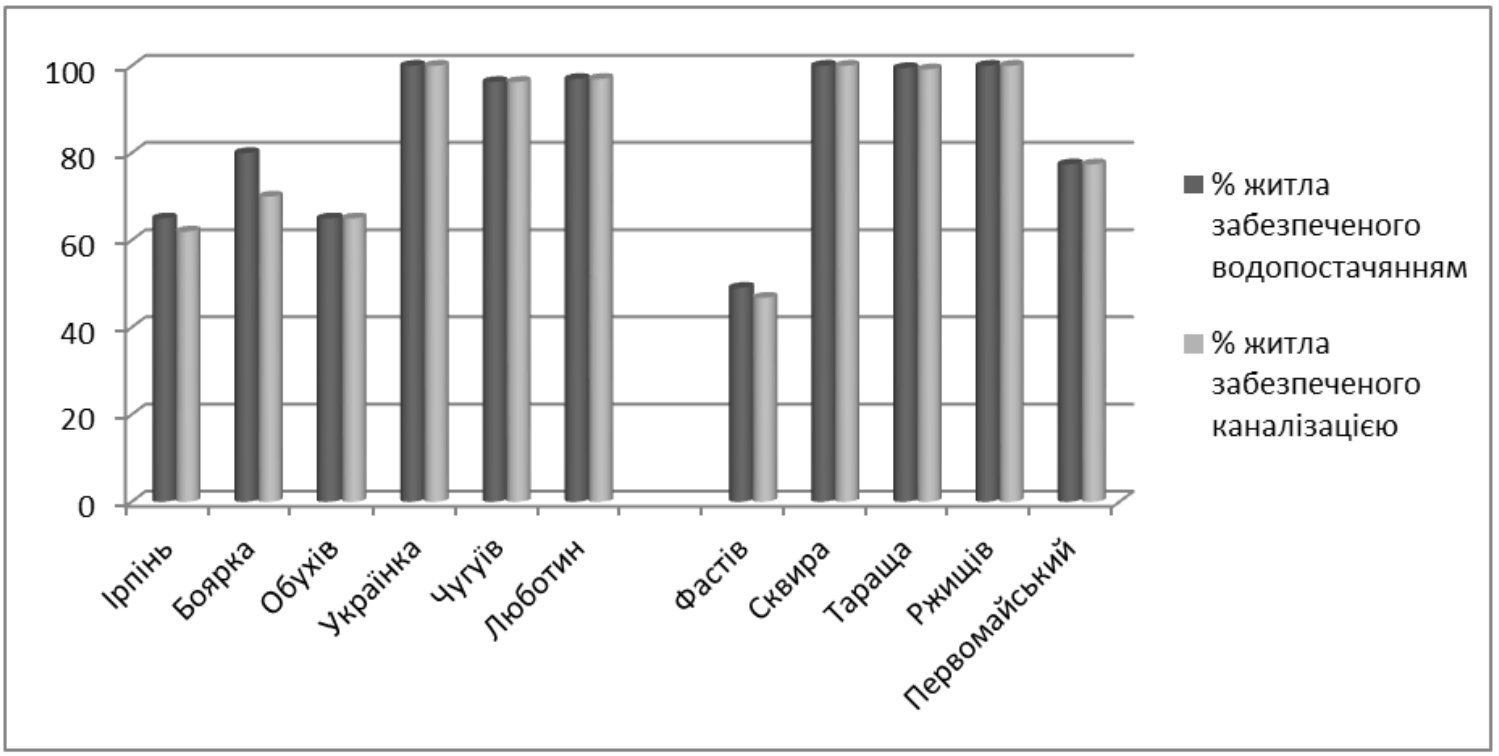

Рис. 4. Забезпеченість житлової площі каналізацією та водопостачанням, 2010 р., \%. Складено за матеріалами [7]

а іiі наявність та стан впливають на розселення населення. Соціальна інфраструктура, що переважно залишилася 3 радянських часів, нині характеризується низьким ступенем задоволення основних життєво необхідних потреб більшості громадян [8]. Мінімальні надходження з бюджету в освіту, медицину, житлово-комунальне господарство призвело до зносу їх основних фондів, зниження рівня наданих населенню послуг. Особливо гостро ці проблеми постають у малих містах, де спектр послуг вужчий, а альтернативи часто майже не має. Значний розрив в умовах життя населення, зокрема у розвитку побутового обслуговування, доступності до закладів культури, медицини, різноманітність закладів дошкільної та середньої освіти, позакласних занять стають ще однією 3 причин відпливу мешканців 3 малих міст. Географічна наближеність до найбільших міст та столиці позитивно впливає на доступність населення малих міст до різноманітних видів послуг особливо при наявності «столичної» зарплати та умов проживання у більш затишному й спокійному малому місті.

Проте, наближеність до великого міста часто не впливає на рівень розвитку житлово-комунального господарства та формування тарифів за надані послуги, а залежить від ефективності діяльності місцевої влади. Зокрема, рівень амортизації систем тепло-, водопостачання та водовідведення на 
підприємствах житлово-комунального комплексу малих міст надзвичайно високий. Ці споруди побудовані переважно в середині минулого століття, внаслідок чого їх технологічний рівень вкрай низький, як і рівень енергоефективності, а стан часто аварійний. Як видно 3 рисунку 4, малі міста, що знаходяться в зоні впливу найбільших міст, характеризуються гіршими показниками забезпеченості каналізацією та водопроводом, ніж малі міста за межами агломерацій.
Перехідний період економіки України характеризується складною ситуацією у освітній та медичній сферах. Зменшення фінансування, спад народжуваності зумовили закриття ряду закладів дошкільної та шкільної освіти, частина приміщень були здані в оренду, деякі заклади перебувають у незадовільному технічному стані. Зростання матеріальної допомоги при народженні дитини, певних позитивних соціально-економічних процесів до 2008 р. зумовив деяке зростання рівня

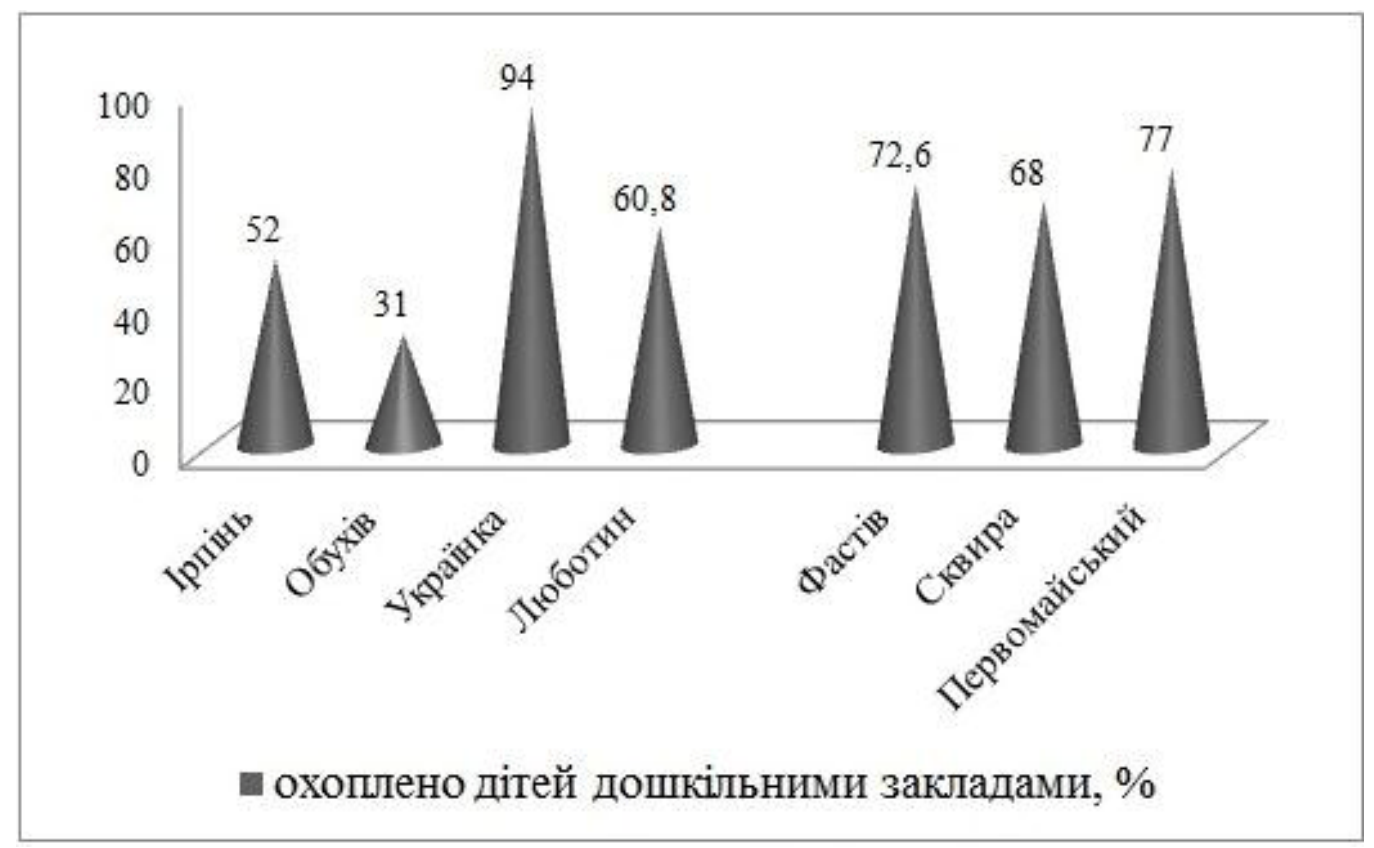

Рис. 5 Охоплення дітей дошкільними закладами, 2010 р.

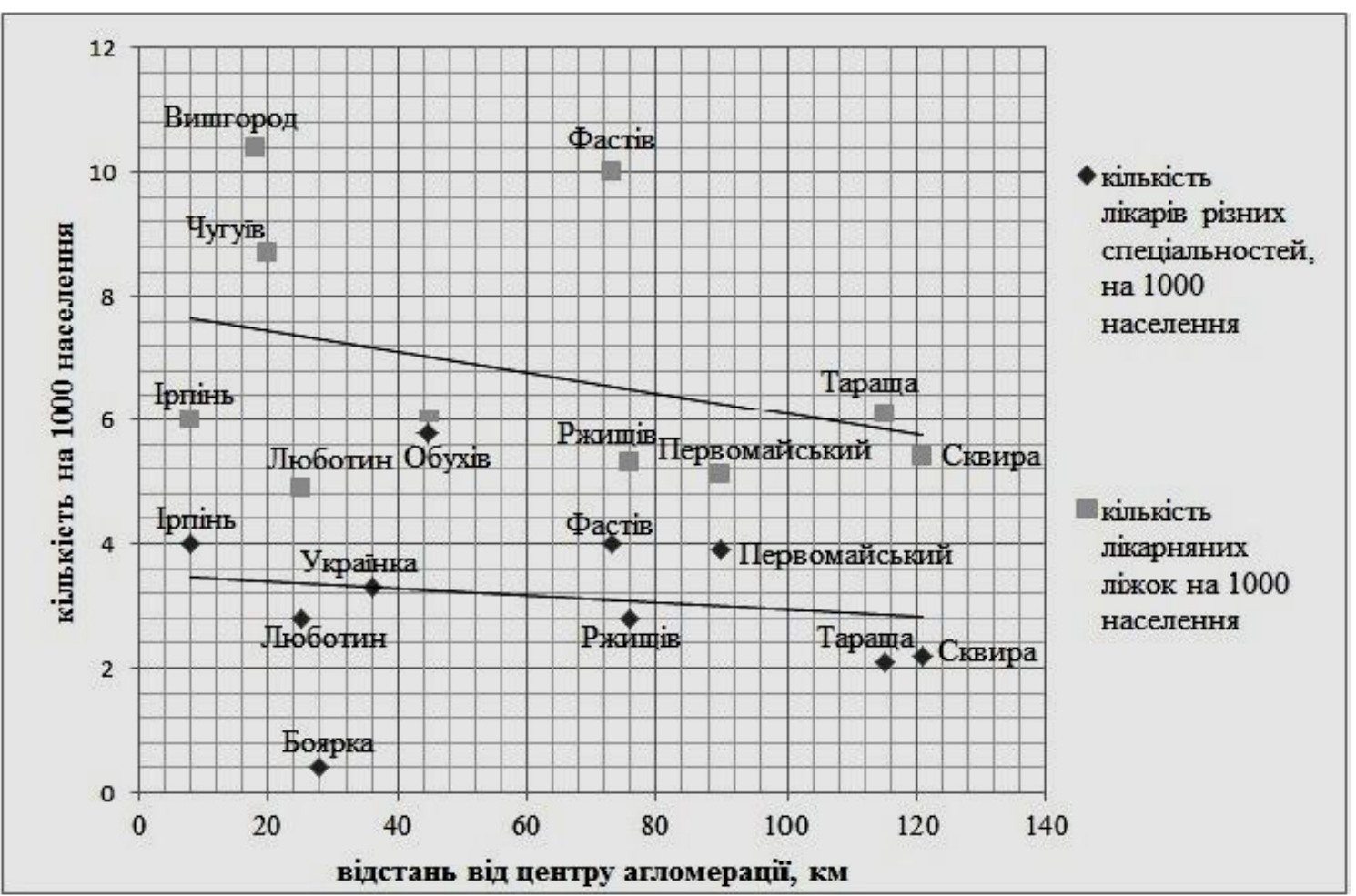

Рис. 6 Кількість лікарняних ліжок та лікарів всіх спеціальностей на 1000 населення, 2010 р. Складено за матеріалами [7] 
народжуваності в Україні, зокрема в містах. У зв'язку 3 цим зросла потреба у дошкільних закладах. Однак, забезпечення дітей закладами дошкільного виховання у малих містах недостатнє, місць для комфортного перебування в них дітей часто не вистачає. Як видно з рис. 5 відсоток охоплення дітей дошкільними закладами незадовільний, в Обухові місцями у дошкільних закладах забезпечені лише третина дітей, у Ірпіні половина. Населення малих міст, що входять до складу агломерацій часто використовуються дошкільні заклади великого міста, де $\epsilon$ великий вибір державних, приватних, англомовних та інших видів закладів. Таким чином, до маятникових міграцій окрім дорослих, що працюють у центрі агломерації, залучаються діти дошкільного та шкільного віку, які також використовують різноманітність закладів позаурочної діяльності, вибір яких у великому місті значно більший. Нестача місць у закладах дошкільного виховання у малих містах поблизу столиці частково пояснюється збільшенням чисельності населення міст, а відповідно - i збільшенням чисельності дітей дошкільного віку. Місцева влада, за браком коштів, часто не в змозі, а деколи не бажає, швидко реагувати на проблеми у сфері дошкільної освіти.

Мешканці малих міських поселень, які віддалені від великих міст, таких можливостей позбавлені. Забезпеченість дітей дошкільними закладами на рівні 60-70 \%, при загальному скороченні чисельності населення малих міст та зменшення народжуваності свідчить про незадовільну роботу місцевої влади в галузі соціальної сфери.

Важливим показником розвитку соціальної сфери є стан системи охорони здоров'я. На жаль, сучасна система охорони здоров'я не відповідає сучасним вимогам та потребує реформування. Неефективність старої системи, недостатне фінансування медицини, нераціональний розподіл коштів між медичними установами в районах призводить до погіршення наданих послуг населенню, доступності до якісного обслуговування та неефективного використання наявних ресурсів охорони здоров'я. Висока зношеність основних фондів у державних та комунальних закладах, технічно та морально застаріла техніка, відсоток якої може досягати 70 \%, низька оплата праці в галузі позбавляе працівників стимулів до якісної роботи, відштовхує молоді кадри, які навчалися у великому місті, повертатися на роботу у регіони [5].

Сучасна система охорони здоров'я характеризується розгалуженою системою закладів, відповідно до Закону України «Про внесення змін до Основ законодавства України про охорону здоров'я щодо удосконалення надання медичної допомоги» формується мережа первинної медикосанітарної допомоги. Однак, проблема доступу до якісних медичних послуг залишається актуальною [10]. Важливим показником, що характеризує рівень розвитку медичного обслуговування, $\epsilon$ забезпеченість лікарями різних спеціальностей та кількість лікарняних ліжок. Як видно з рис. 63 віддаленням від найбільших міст кількість лікарів різних спеціальностей та кількість лікарняних ліжок у малих містах зменшується.

3 наближенням до центру агломерації обидва показники зростають. Також населення малих міст, що входять до складу агломерацій мають доступ до державних, спеціалізованих та приватних медичних закладів у великому місті. Проте, слід зазначити, що статистичні показники кількості лікарів та лікарняних ліжок, лише приблизно відображають доступність населення до медичних послуг, адже вони часто не враховують районні та відомчі лікарні, послугами яких населення також користується.

Висновки. Малі міста використовуючи переваги свого положення - поблизу найбільшого міста характеризуються кращими соціально-економічними показниками розвитку. У них відбувається диверсифікація господарства і зайнятості населення, перерозподіл потенціалу між великим містом та навколишніми малими містами, більш високі доходи населення та нижчий рівень безробіття, що дає можливість призупинити відтік населення.

3 наближенням до центру агломерації, особливо столичної, характерна краща демографічна ситуація, збільшення чисельності населення малих міст або нижчі показники відтоку населення. Однак, суттєво соціально-економічна ситуація відрізняється лише у малих містах навколо столиці, навіть м. Харків здійснює значно менший вплив на навколишні поселення.

Малі міста, що не зазнають впливу найбільших міст переважно характеризуються зростанням рівня безробіття, зниженням платоспроможності населення, змушеність майже в повному обсязі витрачати свій дохід на товари першої необхідності жертвуючи культурними заходами, якісними послугами охорони здоров'я та освіти, що призводить до зниження культурного рівня, зміни суспільних та індивідуальних цінностей. У цих умовах падає духовність суспільства, зростає моральна деградація, соціальні хвороби та злочинність.

Умови життя населення малих міст, що знаходяться у складі агломерацій, є кращими за рахунок сусідства $з$ великим містом і можливостям, які воно надає мешканцям оточуючої території. Однак, такі складові умов життя, як стан житловокомунального господарства, благоустрій внутрішніх територій тощо, значною мірою залежить від політики місцевої влади, взаємоузгодженості у плануванні заходів між містом i місцевою громадою, виконанням загальнодержавних програм розвитку малих міст.

\section{References:}

1. Čisel'nist' nâ̂vnogo naselennâ Ukrä̈ni na 1.01.2011 r. [The population of Ukraine for 01.01.2011]. Edit. Timošenko G.M. The State Committee of Statistics of Ukraine. Kyiv, 2011, 112 p. (In Ukrainian). 
2. Čisel'nìst' naâvnogo naselennâ Ukraïni na 1.01.2014 $r$. [The population of Ukraine for 01.01.2014]. Edit. Timošenko G.M. The State Committee of Statistics of Ukraine. Kyiv, 2014, 112 p. (In Ukrainian).

3. Gukalova İ.V. Akkist' žittâ naselennâ Ukraïni: suspil'no-geografična konceptualìzaciâ [Quality of life in Ukraine: human-geographical conceptualization]. Kyiv, 2009, 347 p. (In Ukrainian).

4. Kovalev S.A. Geografiâ potrebleniâ i geografiâ obsluživaniâ naseleniâ [Geography of consumption and geography of services]. Vestnik MGU, Ser. 5. Geografia [Bulletin of Moscow State University, Series 5: Geography], 1966, N. 2, pp. 3-10. (In Russian).

5. Lehan V. M., Slabkij G. O., Ševčenko M. V. Strategiâ rozvitku sistemi ohoroni zdorov’â: ukraïns'kij vimìr [The development strategy of the health system: Ukrainian dimension]. Ukraïna. Zdorov'a nacii [Ukraine. Health of the nation], 2010, N. 1 (13), pp. 5-23. (In Ukrainian)

6. Nekos A. N., Kravčenko O. K. İstoriâ formuvannâ ta sučasnì doslìdžennâ malih mìst [The history of small towns development and their modern research]. Vìsnik HNU ìmenì V. N. Karazina, Serîa «Ekologiâ» [Bulletin of Karazin Kharkiv National University. Ecology Seriaes], 2014, N. 1104, Vol. 10, pp. 80-87 (In Ukrainian).

7. Osnovni social'no-ekonomičnì pokazniki mist za $2010 \mathrm{r}$. [The main socio-economic indicators of cities for 2010]. Kyiv, Association of Ukrainian Cities, 2011, 81 p. (In Ukrainian).

8. Pakulìna A.A Doslìdžennâ osoblivostej socìal'noï sferi Ukraïni v umovah globalìzaciï ekonomìki ta analìz transformaciï ïi ìnstitucìnnogo seredoviŝa [Studies of social Ukraine in conditions of economic globalization and the transformation of its analysis of the institutional environment]. Ekonomičnij prostir [Economic space], 2014, N. 84, pp. 80-88. (In Ukrainian).

9. Poklâc'kij S.A. Novij poglâd na doslìdžennâ ponâtìjno-termìnologičnih aspektìv (na prikladì kategoriï umovi žittâ naselennâ) [A new look at conceptual and terminological aspects of research (at example of the category "living conditions of the population")]. Ukraïns'kij časopis social'no-ekonomičnoï geografï [Ukrainian Journal of SocioEconomic Geography], 2014, Vol. 16 (1), pp. 33-42 (In Ukrainian).

10. Slabkij G.O., Lehan V.M., Nadutij K.O., Âŝsenko Û.B., Ševčenko M.V., Kondratûk N.Û., Znamens’ka M.A. Deâkì uroki reformi ohoroni zdorov'â Ukraïni [Some lessons of health reform in Ukraine]. Ukraïna. Zdorov'â nacï [Ukraine. Health of the nation], 2014, N. 3 (31), pp. 7-20. (In Ukrainian). 